\title{
Designing Online Learning Evaluation in Times
}

\section{of Covid-19 Pandemic}

\author{
Bambang Suswanto ${ }^{1}$, Adhi Iman Sulaiman ${ }^{1}$, Toto Sugito ${ }^{1}$, Sri Weningsih $^{2}$, Ahmad Sabiq $^{1} \&$ Bambang Kuncoro $^{1}$ \\ ${ }^{1}$ Faculty of Social and Political Science, Jenderal Soedirman University, Indonesia \\ ${ }^{2}$ Indonesia Open University in Purwokerto, Central Java Province of Indonesia \\ Correspondence: Adhi Iman Sulaiman, Kampus road, number 12, Purwokerto City, Central Java Province of \\ Indonesia. 53122. Tel: 62-8163-529-4. E-mail: riset.88pemberdayaan@gmail.com
}

Received: April 14, 2021; Accepted: May 2, 2021; Published: May 2, 2021

The research is financed by Institute for Research and Community Service of Jenderal Soedirman University.

\begin{abstract}
The research objective is to design of learning evaluation that becomes strategy in the Covid Pandemic 19. The study used qualitative research methods with case studies that construct unique and important special realities through data collection interviews and discussions by using case study analysis. The data was collected through online media such as google meetings as well as direct observation from informants, who were determined by purposive sampling, namely the management and student representatives of study groups at the Open University of Purwokerto City and private education institution of Pakis school in Cilongok District in Banyumas regency, Central Java of Indonesia. The research result that the process of service and implementation of education as well as its evaluation during the Covid-19 pandemic must still take place using adaptation and innovation strategies in the form of online learning media through the application media for the Microsoft Teams and Learning Management System (LMS) program. Implementing innovative learning through online media has been successfully implemented practically and effectively, but there is still a need for special socialization and training on an ongoing basis. Evaluation of services and implementation of education is very important to do to provide program improvement and results and evaluation could be effectively carried out through google form and Learning Management System (LMS).
\end{abstract}

Keywords: innovative education, learning evaluation, digital learning media

\section{Introduction}

Open University is a role model in implementing education that educates the nation's life by conducting instructorial education system. Open University is an important part of organizing education as strategic foundation in building and developing the quality of Human Resources (HR) to carry out the constitutional and state mandates, namely enrich the life of a nation. Open University instructorial education is a medium for improving the quality of human resources and educating with the most affordable, democratic, close and friendly way to the community of remote areas, because every person in the community can study in Open University regardless their age and social status and they can study at Open University with a time and place that is adjusted to their abilities. Even the service and education system at the Open University can be a role model for other educational institutions, especially in remote research locations provided with facilities and internet access as a medium for service and education in the digital era.

Educational institutions need to evaluate teaching management, which is very important and strategic for determine the achievements, successes, input and improvement of programs, implementation or policies in order to ensure the quality for public, then a planned learning program to improve services, knowledge and skills as a regulatory standard for external accreditation evaluation assessments (David \& Annunziata, 2001; Lederman \& Lederman, 2017; Sanli, 2019; Sims \& Brettig, 2018)

Educational institutions can also develop e-learning that is built into a learning system by identifying and recognizing readiness about systems and commitments that support the e-learning development, and then need adjustments in the training system, applications from learning organizations, e-learning development teams, 
learning materials, services learning, network facilities, bandwidth, equipment, and funds to support the interactive process of learning (Jin et al., 2020; Mor \& Winters, 2007; Suparto, 2012; Tan 2013). Education is organized with the management and service of learning programs that create student independence in learning, places, facilities, instructorial processes, and student satisfaction that affect learning outcomes, and the real time online system as the digital media to increases public trust and increases the effectiveness of implementing new student admissions (Ardhi, 2015; Suratno, 2018; Suryanto et al., 2013; Wardrip \& Shapiro, 2016) Evaluation of the school's internal quality assurance system is carried out by discussing or sharing the results of observations from the Team and the observed teachers, both individually and in groups to be adjusted to the operational standards of the education system that have been set in schools (Aimah \& Purwanto, 2019; Prastati, 2011; Sitthisak, 2008; Suratno, 2018). Open University needs to continue to carry out a sustainable and comprehensive evaluation through discussion studies and research in order to accommodate aspirations, input or recommendations and the participation of all parties, especially instructors, Study groups and students as positive and constructive as well as scientific contributions to improve service quality strategies and instructorial education of Open University. Thus, it becomes important and interesting to examine the Face-to-Face instructorial program evaluation strategy to improve the quality of service and education in the Program Unit Distance Learning at the Open University of the City of Purwokerto, Central Java, which has a very large and potential enthusiast. It is recorded that the number of active students until 2020/2021 is 10,000 students both in the Basic Education and Non-Education study programs. Open University instructorial education participates in improving the quality of human resources that are affordable, close and friendly in terms of time, place and cost for the community to remote areas, for all ages and social status. All can get education at Open University. It is necessary to carry out periodic and comprehensive evaluations, through discussion studies and research in order to accommodates the aspirations and recommendations of all parties such as instructors, study groups and instructor participants as a constructive and scientific contribution in improving the quality of service and education at Purwokerto which has potential enthusiasts and very large in the regency of Banyumas, Purbalingga, Cilacap and Kebumen areas, Central Java province of Indonesia.

The face-to-face instructorial education management system at the Open University is comprehensive and has quality standards of education by implementing (1) Socialization and instructorial training and instructor training which is always carried out every semester before the implementation of the instructorial to increase motivation, quality of planning and development of instructorial methods, socialization of assessment and evaluation of instructorials. (2) Provide guidelines for the design, implementation and evaluation of instructorials. (3) instructors are selected administratively and interviewed with competency qualifications in the instructorial. (4) The instructor prepares a course competency map, instructorial activity design, instructorial Program Unit, description of assignments, instructorial assignment criteria and grids as well as meeting notes submitted and endorsed by the Open University of Purwokerto leadership before the instructorial process. (5) Monitoring and evaluation of the instructorial process at the beginning and at the end. (6) The instructor becomes a motivator, facilitator and teacher for eight meetings with the target of mastering modules and fostering independent learning. (7) Collecting instructorial reports such as assignment attendance lists, meeting notes, and material slides, grade lists, answer sheets for three instructorial assignments and answer files for the smallest and largest grades, reports are submitted to the Distance Learning Program Unit of Open University and input or uploaded by instructor in the learning system through the website instructor https://instructorial.ut.ac.id.

In improving the quality of service and face-to-face instructorial education, evaluation is needed as an important stage in the management system, including Open University instructorial education. The implementation of evaluation is very important and strategic to improve the quality standard in terms of effectiveness, achievement of outputs and benefits through a process of identification, analysis and assessment starting from planning and implementing instructorials.

Based on the experience of being a instructor and research study (2019-2020), there are several problems in implementing the Open University instructorial, the room facilities and instructorial media are still limited, administrative problems and instructorial schedules are still changing during one and two meetings, remote locations that hinder the instructorial process, low self-learning and less interactive. The service and learning process must still continue even during the Covid 19 Pandemic as a form of commitment in order to educate the nation's life that must not be stopped. The Covid 19 pandemic that has spread around the world starting in 2020, including in Indonesia, according to data from management agencies of Covid-19 has 1.4 million confirmed cases, 1.2 million were declared cured and 39 thousand died, while in Central Java Province in August 2020 there were 9.6 thousand confirmed cases, consisting of 3,097 patients treated, 5,703 patients recovered, and 868 patients died. The Covid 19 pandemic resulted in almost all activities being stopped, starting from economic, socio-religious and cultural activities including the educational process. However, the Covid 19 pandemic made learning become 
challenging. It should be addressed wisely and people seek various solutions to carry out life activities including the learning process. Thus, the open university implements service and education programs using an online system via internet media such as the application of the Microsoft Teams program and with the virtual class. Online instructorial learning (OTL) is a class provided in the Learning Management System (LMS) to help instructors provide space to deliver learning material, and the administration of OTL. The virtual class can be accessed via the website, which has been implemented by the Open University including for the Distance Learning Program Unit at the Open University of the City of Purwokerto, Central Java in the Covid 19 Pandemic era to be precise from early 2020 to mid 2021.

Researchers consider that it is important to carry out research to design of instructorial learning evaluation was needed both with online and face-to-face learning program systems in the Distance Learning Program Unit at the Open University of Purwokerto, Central Java. The results of the evaluation can be used as material for socialization and implementation of the basic principles of social engineering under study and applications that can be formulated as input for planning service improvement programs and implementing the learning process. Therefore, it is necessary to add group, field or case study assignments. So it becomes important and interesting to research the evaluation strategy of face-to-face instructorial programs to improve the quality of service and education at Open University of Purwokerto which can be adopted by private education institution Tsyanawiyyah Pakis.

\section{Method}

The research used a qualitative case study method, according to Rashid et al. (2019) qualitative case study allows researchers to carry out in-depth exploration of unique and interesting phenomena in a particular context which is carried out through four stages, namely the foundation phase, the pre-field phase, the field phase and the reporting phase. The study used purposive sampling to determine informants, namely the management and student representatives of study groups of the Open University of Purwokerto City and private education institution Tsyanawiyyah Pakis in Cilongok District in Banyumas regency, Central Java of Indonesia. Data was collected through interviews and direct discussions, while maintaining the health protocol and through online media such as zoom meetings and google meetings. Data was collected trough documentation of service and learning process files from both the management and study group students as well as from instructors as teachers.

Research data analysis was carried out in case studies by carrying out a systematic amalgamation as a process in which the theoretical framework and results of field work are interpreted empirically and the causality of findings is sought simultaneously as a form of developing new concepts and theories as study material for further research (Creswell et al., 2007).

\section{Results and Discussion}

The research is designed through a preliminary study stage in 2019 to early 2020 before the Covid 19 pandemic such as observation, collecting documentation data, and interviews with research locations, reviewing research results and scientific journals as well as academic studies with colleagues, experts and practitioners, especially regarding education management and educational evaluation of online learning education. The online learning evaluation design at the open university is very relevant to the adoption of the Pakis school which has educational characteristics with teaching in the environment to explore protected forests and agriculture. Pakis Schools can make online-based teaching and services as an alternative to adaptive and innovative learning methods in the Covid 19 situation, which is limited to normal face-to-face education. So it is necessary to conduct workshops and comparative studies to the Open University in the City of Purwokerto to adopt online learning and services, especially for school management, teachers and students.

\subsection{Education Trough Online Learning Program}

The students of distance programs such as Open University have difficulties such as feeling bored because they do not interact or isolated, difficulty in understanding teaching materials, and difficulty in getting feedback on questions and assignments given and are not accustomed to distance learning, because they are used to learning face-to-face and there is instructor (teacher) guidance in the class at the previous school. Thus, the distance education system requires an academic program in the form of face-to-face instructorial services in order to help students optimally in the learning process. Based on the Regulation of the Minister of Education and Culture number 24 of 2012 concerning the Implementation of Distance Education in Higher Education, Article 1 (4) states that instructorials are a form of academic learning assistance that can be implemented face-to-face or through the use of information and communication technology.

The development of the education delivery system in the era of globalization and digitalization has used web and internet-based technology media. However, face-to-face learning still has to be carried out with appropriate 
learning methods in achieving learning objectives, expected outcomes and motor skills as well as changes in behavior attitudes (Hammond et al., 2020; Mayers, 2013; Widyaningrum \& Prihastari, 2020). According to the 2019/2020 Open University Organizing System Catalog, instructorial is a instructoring and assistance program organized by Open University from instructors aimed at supporting the student's independent learning process both individually and in groups. The implementation of instructorials at Open University has the first form of online instructorials through the learning process using the media website at https://elearning.ut.ac.id/. Both Face-to-Face instructorials are learning assistance services through face-to-face meetings or lectures between instructors and students as many as eight meetings for one semester.

During the Covid 19 pandemic, a instructorial process was carried out with an online system through the Microsoft Teams class in the even semester from March to August 2020 and in the next semester; from September to December 2020 using virtual class Online instructorial learning (OTL). OTL is a class provided in the Learning Management System (LMS) to help instructors provide space to deliver learning materials, organizing Online instructorial learning. The OTL class can be accessed via the https://ms.ut.ac.id/ page. The creation of the OTL class will be carried out by the Open University Learning Assistance Center based on the instructorial class permit data.

Programs and processes for implementing education by adapting and innovating using technological media have become a development of the challenges and demands of the times in the era of information and communication technology which are very important as an effective strategy especially in emergencies such as the Covid 19 Pandemic (An \& Oliver, 2021; Moorhouse, 2020; Sabiq et al., 2020; Sulaiman et al., 2020; Verma., 2020; Williamson et al., 2020).

The use of service and learning media through the Learning Management System (LMS) is carried out in several stages, namely (1) Preliminary session which contains instructions for the content of information that must be explained in the introductory session, the introduction menu, the introductory forum, the discipline menu and the rules for implementing Online instructorial learning (OTL). The OTL classroom preparation that instructors need to do in the introductory session by updating the explanation that contains information: (a) The name and eye code according to the catalog, (b) The instructor's name and email address, (c) Greetings and motivation, (d) The discussion material to be presented in OTL for the next 8 week meetings, (e) The expected course learning outcomes that are expected to be achieved through the entire series of OTL activities, and (f) Closing greetings.

(2) In the OTL class instructorial session, starting from the 1st meeting to the 8th meeting session provides instructions on the content of information that must be explained in the 1st to 8th session of the OTL class. Then menus such as material, discussions, lecture meetings, assignment submissions, evaluation questionnaires and value summaries have been provided with details of the following activities: (a) Updating the explanation of each containing title information or the topic of each lecture session, (b) Greetings and giving motivation, (c) The scope of the discussion material that will be presented in OTL for each session, (d) The scope of activities that will be provided in the OTL class in each session, (e) the expected learning outcomes of the courses that are expected to be achieved through a series of activities OTL for each session, (f) Uploading learning material, both material to be presented at the OTL and supporting material, which are expected to help students in preparation for learning before attending the OTL for each session. The types of documents that can be used in presenting material in the OTL class including presentation documents (power point slides), learning videos, and links from open learning resources as well as Open Educational Resources (OER) on a website. Each learning material that has been uploaded in each session must be placed under the material menu in each session. (g) Updating the explanation at the discussion venue for each session which contains discussion topics that must be responded to by students, both before the OTL and after the OTL for each session. (h) Updating the explanation at the OTL attendance place for each session. (i) Updating the explanation at the OTL link which contains information on the OTL schedule for each session. (j) Specific for the 3rd session, 5th session, and 7th session, instructors are expected to update the explanation of the assignment collection point which contains information on how to do the assignment, about assignments, and time for submitting assignments. $(\mathrm{k})$ At the end of the 8th session, instructors are expected to enter the OTL final score and upload the OTL report through the score entry application on the website of Open University Department.

Instructorials facilitate and motivate the learning process of students who are expected to have the motivation and ability to think, learn, observe, behave and carry out the goals of each course. The success of instructorials is determined not only by student motivation and abilities but also by the instructor who has the influence to become a facilitator or teacher. Learning processes such as instructoring and mentoring require participatory communication that is dialogic, egalitarian and empowering (Bhattacharya, 2020; Lawson, 2011; Martin \& Lawson, 2013; Sulaiman \& Ahmadi, 2020). 


\subsection{Designing Evaluation of Online Educational}

Management has elements that cannot be separated from each other or a complementary unit starting from planning, organizing, implementing and evaluating. In assessing or measuring the success of management and making appropriate, effective and accurate decisions, proper evaluation activities and accurate information data are needed.

Evaluation serves to identify problems and opportunities to meet and assess needs and explain the relevant context. Evaluation can be carried out before, during the process, and after the program is implemented, the results of the evaluation can become recommendations for materials for decision making or strategies to maintain, modify or improve things that are is no longer relevant (Arini et al., 2021; Daniel, 2020; Datta, 2007; Kurnia et al., 2017).

Characteristics in face-to-face education programs at Open University can be identified and analyzed by these three important components, namely: planning, implementation, and program results. Hence, to develop a face-toface instructorial program evaluation strategy Open University can use three components in the evaluation strategy (Planning, Implementation, and instructorial Results). Evaluation of the planning component is focused on perceptions of program management, independence of students in learning, and perceptions of place and instructorial facilities. Evaluation of program implementation is focused on the quality of the instructorial process. Evaluation of program results is focused on student satisfaction and learning outcomes.

Based on these, a face-to-face instructorial program management evaluation scheme can be made which will be used as research indicators, as in Figure 1.

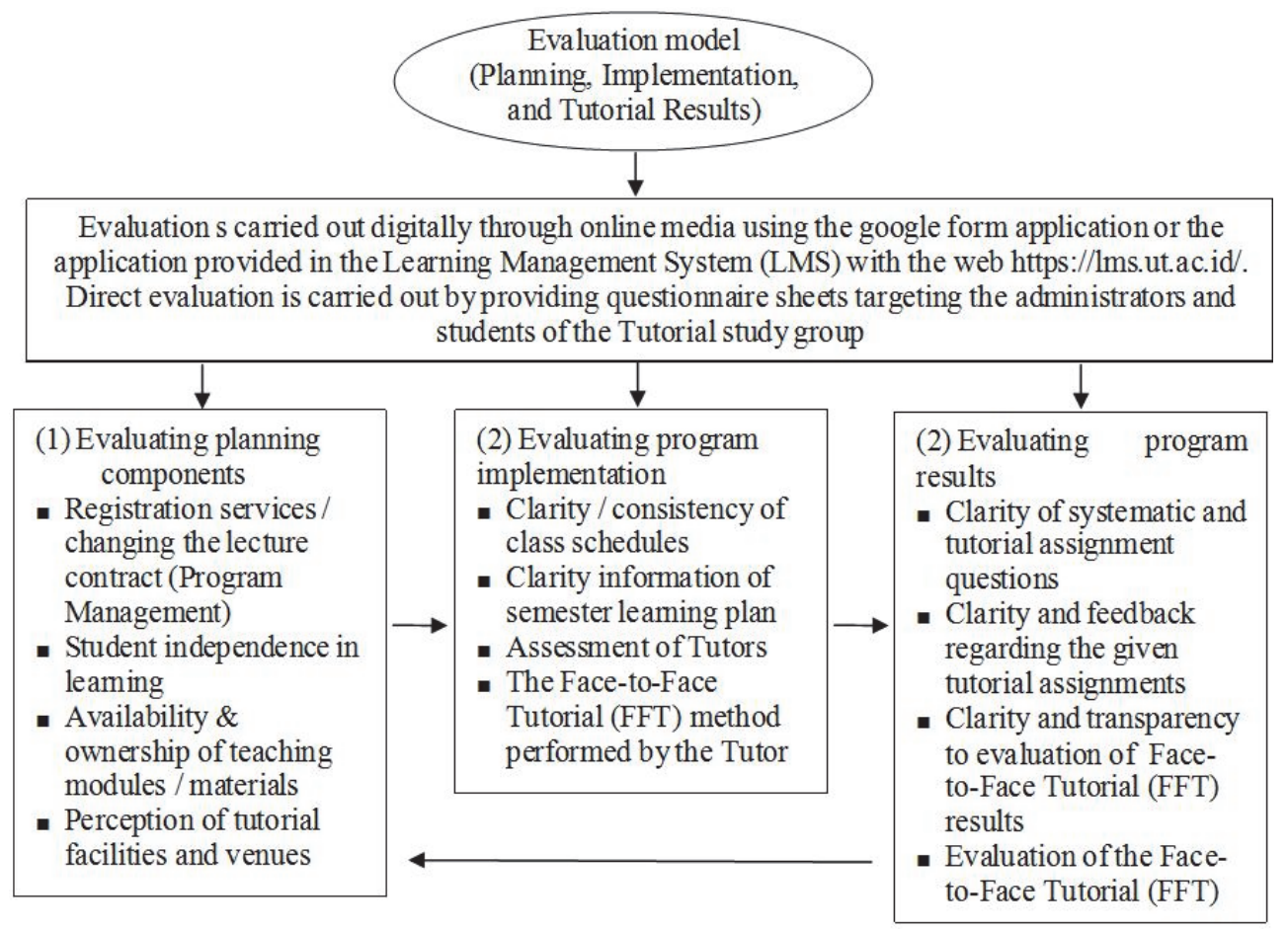

Figure 1. Evaluation model (Planning, Implementation, and Tutorial Results)

Quality educational institutions demand effective and efficient institutional management from the aspects of human resources, funds, and infrastructure as well as leaders and teachers who are open and adaptive to achieve goals. Quality standard education is not only judged by the quality of its graduates, but also related to customer indicators, namely: (1) Customer satisfaction, (2) Increasing customer interest and expectations, (3) Pleasing customers (Daniel, 2020; Hillman \& Säljö, 2016; Khan \& Usman, 2015; Vargas, 2015).

Based on the National Education Standards Agency, the National Education Standards (2019) consist of (1) Graduate Competency Standards, (2) Content Standards, (3) Process Standards, (4) Education Standards and Education Personnel, (5) Facilities and Infrastructure Standards, (6) Management Standards, (7) Education Financing Standards, (8) Education Assessment Standards.

Improving the quality of education in tertiary institutions is an important and strategic matter to continue with the strategy of improving the human resource subsystem, organizational structure, use of technology, and 
organizational implementation processes. The higher education strategies in increasing quality graduates include: (1) Students as learners; (2) teaching staff or lecturers as educator (3) facilities and infrastructure (Asmawi, 2005; Bauman, 2009; Huiru, 2014; Spante et al., 2013).

Evaluation is an activity of collecting, analyzing, presenting important data and information to consider better decisions with indicators (1) readiness of lecturers, (2) readiness of the organizing team and (3) readiness and completeness of infrastructure or facilities (Budi et al., 208; Divayana \& Sugiharni, 2016; Voigt \& Swatman, 2010) Evaluation of the instructorial program assess the quality assurance of the Distance Learning Program Unit of Open University which provides open opportunities for students to be involved in evaluating the instructorial process regularly and continuously at each instructorial stage using the "instructor Evaluation Questionnaire" instrument (Sugiran et al., 2016).

Table 1. Educational evaluation implementation design

\begin{tabular}{|c|c|c|}
\hline No. & Activity Name & \\
\hline 1. & $\begin{array}{l}\text { Preliminary Study: literature review, } \\
\text { observation, interviews, opening of access and } \\
\text { discussions with colleagues }\end{array}$ & $\begin{array}{l}\text { Able to identify \& formulate problems, objectives, } \\
\text { locations \& research methods Compiling \& submitting } \\
\text { research proposals }\end{array}$ \\
\hline 2. & $\begin{array}{l}\text { access and approach to location as } \\
\text { istributing questionnaires }\end{array}$ & $\begin{array}{l}\text { Researchers get perm } \\
\text { research location Obt }\end{array}$ \\
\hline 3. & $\begin{array}{l}\text { and analysis of the results of the } \\
\text { ire }\end{array}$ & potential of ex-drug \\
\hline 4. & $\begin{array}{l}\text { ementation of FGD I identified } \\
\text { potentials and prospects }\end{array}$ & ied by FGD \\
\hline 5. & $\begin{array}{l}\text { ssing and analysis of the results of the } \\
\text { I }\end{array}$ & $\begin{array}{l}\text { Identified problems and eva } \\
\text { instructorial programs at } \mathrm{Op}\end{array}$ \\
\hline 6. & $\begin{array}{l}\text { Implementing PDM of practitioners and } \\
\text { leaders of Open University of Purwokerto }\end{array}$ & orial \\
\hline 7. & $\begin{array}{l}\text { g interviews and observations and } \\
\text { ation of study groups research } \\
\text { Open University of Purwokerto }\end{array}$ & $\begin{array}{l}\text { The results of the questionnaire, FGD I and III can be } \\
\text { verified and triangulated Get more in-depth and complete } \\
\text { data }\end{array}$ \\
\hline 8. & $\begin{array}{l}\mathrm{g} \text { and analysis of the results of the } \\
\text { of the face-to-face instructorial } \\
\text { it Open University of Purwokerto }\end{array}$ & $\begin{array}{l}\text { Able to produce an evaluation of the face-to-face } \\
\text { instructorial program at Open University of Purwokerto } \\
\text { Producing papers and journal articles }\end{array}$ \\
\hline 9. & $\begin{array}{l}\text { Seminar on research results and preparation of } \\
\text { reports }\end{array}$ & $\begin{array}{l}\text { Get input on the results of the seminar } \\
\text { Can prepare and submit research reports on time }\end{array}$ \\
\hline 10. & $\begin{array}{l}\text { Meeting with government stakeholders } \\
\text { conducted socialization and provided } \\
\text { recommendations for research results }\end{array}$ & $\begin{array}{l}\text { The educational institution of the Purwokerto Open } \\
\text { University, Central Java Madrasah Tsanawiyah Pakis } \\
\text { Cilongok educational institution, Banyumas Regency, } \\
\text { Central Java Community and education activists }\end{array}$ \\
\hline 11. & $\begin{array}{l}\text { Process, analyze, and compile Research } \\
\text { reports }\end{array}$ & $\begin{array}{l}\text { Reports can be compiled Reports can be prepared and } \\
\text { submitted }\end{array}$ \\
\hline 12. & Scientific publications & $\begin{array}{l}\text { ablish research results to scientific journals, } \\
\text { a mass media }\end{array}$ \\
\hline
\end{tabular}

The the concept of evaluation design can be designed as questionnaire either given directly or through online media such as google form or educational websites to respondents, such as study group administrators and students, namely:

(1) Sample questionnaire for service evaluation and cooperation with educational institutions intended to obtain information about partner satisfaction level with cooperation programs conducted with educational institutions such as Open Universities or other institutions. The questionnaire is filled out by respondents giving a score of 4, 3,2 , or 1 for each aspect of the services provided by placing a cross in the available column. The higher the score given by the respondent, the higher the level of satisfaction with each aspect of the services provided by educational institutions are, as in table 2. 
Table 2. Sample questionnaire for service evaluation and cooperation

\begin{tabular}{llllll}
\hline & \multicolumn{1}{c}{ Service Aspects } & \multicolumn{3}{c}{ Satisfaction Assessment } \\
\hline 1. & Easy to obtain information to establish cooperation & 4 & 3 & 2 & 1 \\
2. & Easy to communicate with Open University & 4 & 3 & 2 & 1 \\
3. & Clarity of the person in charge of cooperation & 4 & 3 & 2 & 1 \\
4. & Speed of completion of cooperation documents & 4 & 3 & 2 & 1 \\
5. & Hospitality in providing services & 4 & 3 & 2 & 1 \\
6. & Speed in providing services & 4 & 3 & 2 & 1 \\
7. & Accuracy in providing services & 4 & 3 & 2 & 1 \\
8. & Thoroughness in solving problems & 4 & 3 & 2 & 1 \\
9. & Flexibility in accommodating changes in cooperation & 4 & 3 & 2 & 1 \\
10. & Implementation of the cooperation program & 4 & 3 & 2 & 1 \\
11. & Implementation of monitoring of cooperation programs & 4 & 3 & 2 & 1 \\
12. & Implementation of cooperation evaluation & 4 & 3 & 2 & 1 \\
13. & Punctual in receiving reports on the implementation of cooperation & 4 & 3 & 2 & 1 \\
14. & Punctual in completing of the cooperation implementation & 4 & 3 & 2 & 1 \\
15. & Achievement of cooperation goals & 4 & 3 & 2 & 1 \\
16. & The benefits of cooperation for partners & 4 & 3 & 2 & 1 \\
\hline
\end{tabular}

(2) Example of a questionnaire to evaluate the implementation of the online instructorial education process. The education implementation evaluation questionnaire can be given to student respondents by giving a score on each statement (based on the student's experience) according to the level of satisfaction and importance weight, by means of a cross mark on the numbers contained in the Satisfaction and Interest column. The higher the score you provide, the higher your level of satisfaction and the more important this aspect of the service is as in table 3 .

Table 3. Example of a questionnaire for evaluation of the educational process

\begin{tabular}{|c|c|c|}
\hline Service aspects & Satisfactory* & Importance** \\
\hline \multicolumn{3}{|l|}{ General service } \\
\hline Clarity of information about UT & 4321 & 4321 \\
\hline Tuition fees paid by students compared to the services provided & 4321 & 4321 \\
\hline Easy to contact Open University Staff & 4321 & 4321 \\
\hline Easy to contact the instructor & 4321 & 4321 \\
\hline Open University staff friendliness in serving students & 4321 & 4321 \\
\hline Complaint handling speed & 4321 & 4321 \\
\hline \multicolumn{3}{|l|}{ Registration service } \\
\hline Registration file processing service & 4321 & 4321 \\
\hline Payment services at Open University partner banks & 4321 & 4321 \\
\hline Registration case resolution service & 4321 & 4321 \\
\hline \multicolumn{3}{|c|}{$\begin{array}{l}\text { This section is only filled in if you have taken either the Face to Face instructorial (FFT) or the Online } \\
\text { instructorial (Tuton). If not, you can immediately fill out aspects of the Teaching Materials Service (Part D) }\end{array}$} \\
\hline instructors Lesson Mastery & 4321 & 4321 \\
\hline $\begin{array}{l}\text { The role of the instructor in helping students understand course } \\
\text { material }\end{array}$ & 4321 & 4321 \\
\hline Feedback provided by instructors on exercises or assignments & 4321 & 4321 \\
\hline Suitability of the instructorial implementation with the schedule & 4321 & 4321 \\
\hline \multicolumn{3}{|l|}{$\begin{array}{l}\text { If you are taking FFT, fill in the number } 14 \\
\text { If you are taking Tuton, fill in the number } 15\end{array}$} \\
\hline Quality instructorial place facilities & 4321 & 4321 \\
\hline Easy access to tutons & 4321 & 4321 \\
\hline \multicolumn{3}{|c|}{$\begin{array}{l}\text { Practical Services or Practicum } \\
\text { This section is only filled in if you take the Practice or Practicum. If not, you can immediately fill out aspects } \\
\text { of the Teaching Materials Service (Part E) }\end{array}$} \\
\hline Instructor's Lesson Mastery & $\begin{array}{llll}4 & 3 & 2 & 1 \\
4 & 3 & 2 & 1\end{array}$ & $\begin{array}{llll}4 & 3 & 2 & 1 \\
4 & 3 & 2 & 1\end{array}$ \\
\hline
\end{tabular}




\begin{tabular}{|c|c|c|}
\hline Service aspects & Satisfactory* & Importance** \\
\hline \multicolumn{3}{|l|}{ practicum } \\
\hline $\begin{array}{l}\text { Feedback provided by the instructor during the practice or } \\
\text { practicum }\end{array}$ & 4321 & 4321 \\
\hline $\begin{array}{l}\text { Easy to obtain a schedule for the implementation of practice or } \\
\text { practicum }\end{array}$ & 4321 & 4321 \\
\hline $\begin{array}{l}\text { The suitability of the practice or practicum implementation with the } \\
\text { schedule }\end{array}$ & 4321 & 4321 \\
\hline \multicolumn{3}{|l|}{ Completeness of practice equipment or practicum } \\
\hline \multicolumn{3}{|l|}{ Lesson material } \\
\hline Easy to obtain teaching materials & 4321 & 4321 \\
\hline The speed of receiving teaching materials & 4321 & 4321 \\
\hline Easy to understand teaching materials & 4321 & 4321 \\
\hline Quality of physical packaging of teaching materials & 4321 & 4321 \\
\hline Easy to use of the TBO application & 4321 & 4321 \\
\hline Availability of teaching materials at TBO & 4321 & 4321 \\
\hline The conformity of teaching materials received with those ordered & 4321 & 4321 \\
\hline Easy to obtain test implementation information & 4321 & 4321 \\
\hline Availability of exam manuscripts & 4321 & 4321 \\
\hline Order of the examination & 4321 & 4321 \\
\hline Quality of location / test site facilities & 4321 & 4321 \\
\hline Value case resolution speed & 4321 & 4321 \\
\hline
\end{tabular}

Note:

* satisfaction level describes the level of student satisfaction with Open University services

** the level of importance of students' perceptions of the importance of related services

\section{Conclusion}

Education is an important and strategic factor in determining the improvement of the human resource quality as actors that will determine the success and progress of development in all fields. The process of service and implementation of education must continue in the midst of the challenges of the Covid 19 epidemic which limits interaction space due to large-scale social restrictions.

The Covid 19 Pandemic period led to good educational ideas and programs that remained productive, creative, and innovative by implementing online education services and processes through various media application programs such as google classroom, google meetings, and zoom meetings at various universities, including the Open University with using the application of the Microsoft Teams and Learning Management System (LMS) media program that has been implemented by the online instructorial class long before the Covid 19 pandemic.

The online educational media that is used by educational institutions, even with situations and conditions between students and instructors, are still considered effective and attractive in the implementation process and the results of their evaluation. Because education through the media of Microsoft Teams and the Learning Management System (LMS) can still be carried out interactively as a form of participatory and empowering education. Online learning media uses more varied and interesting material for the learning process starting from shows from videos such as YouTube, news online and online references such as scientific journals and electronic books (e-books).

The successful implementation of the service and learning process through online methods such as by the Open University in Purwokerto City, can be adopted by other educational institutions such as educational institutions in remote areas with requirements for the availability of equipment and internet media access, including Madrasah Pakis Cilongok school, Banyumas Regency which has a characteristic as a natural school or green school.

The implementation of educational activities must still be improved by an evaluation program of service and learning processes in order to receive constructive input in increasing satisfaction, improvement and quality of education, especially by implementing online education. The preparation of equipment and access to online learning media is an important element with comprehensive and continuous socialization and training for operators, administrators, instructors and student in an adaptive, creative, and innovative online learning process.

Pakis school as a model of natural education with a green school motto that prioritizes face-to-face teaching and practice in agriculture and protected forests, but is still relevant to adopting online learning technology so that there is a balance between character education and technology education, especially during the Covid 19 pandemi 
must be maintain social distancing to interact. Pakis school activities can also utilize technology and communication media for learning media to present and publish the uniqueness of learning in nature based on green to school.

\section{Acknowledgments}

We would like to thank fot the Institute for Research and Community Service of Jenderal Soedirman University for providing opportunities and supporting by our research, and then for research informants, who have supported and participated in the research.

\section{References}

Aimah, S., \& Purwanto, B. (2019). Evaluating teachers' performance: A need for effective teaching. A Journal of Culture, English Language Teaching \& Literature, 19(1), 158-170. https://doi.org/10.24167/celt.v19i1.1369

An, T., \& Oliver, M. (2021). What in the world is educational technology? Rethinking the field from the perspective of the philosophy of technology. Learning, Media and Technology, 46(1), 6-19. https://doi.org/10.1080/17439884.2020.1810066

Ardhi, M. I. (2015). Evaluasi manajemen penerimaan peserta didik baru sistem real time online dinas pendidikan kota Yogyakarta. Jurnal Penelitian Ilmu Pendidikan, 8(1), 80-94. https://doi.org/10.21831/jpipfip.v8i1.4930

Arini, P. D., Matin, M., \& Zulaikha, S. (2021). Curriculum management during the covid-19 emergency. Journal of Education Research and Evaluation, 5(2), 107-116. https://doi.org/10.23887/JERE.V5I2.31593

Asmawi, M. R. (2005). Strategi meningkatkan lulusan bermutu di pergutuan tinggi. Makara Human Behavior Studies in Asia, 9(2), 66-71. https://doi.org/10.7454/mssh.v9i2.124

Bauman, Z. (2009). Education in the liquid-modern setting. Power and Education, 1(2), 157-166. https://doi.org/10.2304/power.2009.1.2.157

Bhattacharya, S. (2020). Education as empowerment: Review of pedagogy of the oppressed. Journal of Political Science Education, 16(3), 403-406. https://doi.org/10.1080/15512169.2019.1632715

Budi, K., Setiawati, A., \& Guntara, D. (2018). Learning, evaluation, and planning (LEAP) model to evaluate the WVIs economic development program in Poso, Central Sulawesi, Indonesia, in The 2nd International Conference on Vocational Higher Education (ICVHE) 2017. "The Importance on Advancing Vocational Education to Meet Contemporary Labor Demands, KnE Social Sciences, 875-903. https://doi.org/10.18502/kss.v3i11.2814

Creswell, J. W., Hanson, W. E., Clark Plano, V. L., \& Morales, A. (2007). Qualitative research designs: Selection and implementation. The Counseling Psychologist, 35(2), 236-264. https://doi.org/10.1177/0011000006287390

Daniel, S. J. (2020). Education and the covid-19 pandemic. Prospects, 49(1-2), 91-96. https://doi.org/10.1007/s11125-020-09464-3

Datta, L. (2007). Evaluation theory, models, and applications, by Daniel L. Stufflebeam and Anthony J. Shinkfield. San Francisco: Jossey-Bass, 2007. 768 pp. \$70.00. American Journal of Evaluation, 28(4), 573-576. https://doi.org/10.1177/1098214007308902

Davis, D. R., Ellett, C. D., \& Annunziata, J. (2002). Teacher evaluation, leadership and learning organizations. Journal of Personnel Evaluation in Education, 16(4), 287-301. https://doi.org/10.1023/a:1021791907098

Divayana, D. G. H., \& Sugiharni, G. A. D. (2016). Evaluasi program sertifikasi komputer pada universitas teknologi Indonesia menggunakan model CSE-UCLA. JPI (Jurnal Pendidikan Indonesia), 5(2), 158-165. https://doi.org/10.23887/jpi-undiksha.v5i2.8586

Hammond, L. D., Flook, L., Cook-Harvey, C., Barron, B., \& Osher, D. (2020). Implications for educational practice of the science of learning and development. Applied Developmental Science, 24(2), 97-140. https://doi.org/10.1080/10888691.2018.1537791

Hillman, T., \& Säljö, R. (2016). Learning, knowing and opportunities for participation: technologies and communicative practices. Learning, Media and Technology, 41(2), 306-309. https://doi.org/10.1080/17439884.2016.1167080

Huiru, Y. (2014). A case study: Innovation of internal teaching and learning evaluation system in higher education institutions. Chinese Education \& Society, 42(1), 95-104. https://doi.org/10.2753/CED1061-1932420108

Jin, L., Wen, Z., \& Gough, N. (2010). Social virtual worlds for technology-enhanced learning on an augmented 
learning platform. Learning, Media and Technology, 35(2), 139153. https://doi.org/10.1080/17439884.2010.494424

Khan, M. A., \& Usman, M. (2015). Education quality and learning outcomes in higher education institutions in Pakistan. In Taylor's 7th Teaching and Learning Conference 2014 Proceedings (pp. 449-463). Springer Singapore. https://doi.org/10.1007/978-981-287-399-6_41

Kurnia, F., Rosana, D., \& Supahar. (2017). Developing evaluation instrument based on CIPP models on the implementation of portfolio assessment. AIP Conference Proceedings, 1868(1), 080003. https://doi.org/10.1063/1.4995187

Lawson, T. (2011). Empowerment in education: Liberation, governance or a distraction? A review. Power and Education, 3(2), 89-103. https://doi.org/10.2304/power.2011.3.2.89

Lederman, N. G., \& Lederman, J.S. (2017). The education and evaluation of effective teaching: The continuing challenge for teacher educators and schools of education. Journal of Science Teacher Education, 28(7), 567 573. https://doi.org/10.1080/1046560X.2017.1407175

Martin, J., \& Lawson, T. (2013). Whose empowerment? The dynamics of power and choice in managing student access to personalised key stage 4 options. Power and Education, 5(2), 159-172. https://doi.org/10.2304/power.2013.5.2.159

Mayers, E. M., Erickson, I., \& Small, R. V. (2013). Digital literacy and informal learning environments: an $\begin{array}{lllll}\text { introduction. } \quad \text { Learning, } & \text { Media }\end{array}$ https://doi.org/10.1080/17439884.2013.783597

Moorhouse, B. L. (2020). Adaptations to a face-to-face initial teacher education course 'forced online due to the covid-19 pandemic. Journal of Education for Teaching, 46(4), 609-611. https://doi.org/10.1080/02607476.2020.1755205

Mor, Y., \& Winters, N. (2007). Design approaches in technology-enhanced learning. Interactive Learning Environments, 15(1), 61-75. https://doi.org/10.1080/10494820601044236

Prastati, T. (2011). Program pelatihan instructor universitas terbuka. Jurnal Evaluasi Pendidikan, 2(2), 206-217. https://doi.org/10.21009/jep.022.08

Rashid, Y., Rashid, A., Warraich, M. A., Sabir, S. S., \& Waseem, A. (2019). Case study method: A step-by-step guide for business researchers. International Journal of Qualitative Methods, 18, 1-13. https://doi.org/10.1177/1609406919862424

Sabiq, A., Sulaiman, A. I., \& Sugito, T. (2020). Family empowerment program as community education in supporting the prevention of the covid-19 pandemic. International Educational Research, 3(3), 22-32. https://doi.org/10.30560/ier.v3n3p22

Şanli, O. (2019). An evaluation of the teachers classroom management problems. Educational Research and Reviews, 14(8), 282-292. https://doi.org/10.5897/ERR2019.3712

Sims, M., \& Brettig, K. (2018). Early childhood education and early childhood development: Do the differences matter? Power and Education, 10(3), 275-287. https://doi.org/10.1177/1757743818771986

Sitthisak, O., Gilbert, L., \& Davis, H. C. (2008). An evaluation of pedagogically informed parameterised questions for self-assessment. Learning, Media and Technology, 33(3), 235-248. https://doi.org/10.1080/17439880802324210

Spante, M., Hashemi, S. S., Lundin, M., \& Algers, A. (2018). Digital competence and digital literacy in higher education research: Systematic review of concept use. Cogent Education, 5(1), 1-21. https://doi.org/10.1080/2331186X.2018.1519143

Sugiran, S., Daulay, P., Zaman, B., Effendy, F., \& Amalia, L. (2016). Evaluasi instructor online untuk meningkatkan kualitas layanan instructorial tatap muka pada pendidikan jarak jauh. Journal of Information Systems Engineering and Business Intelligence, 2(1), 1-10. https://doi.org/10.20473/jisebi.2.1.1-10

Sulaiman., A. I., \& Ahmadi, D. (2020). Empowerment communication in an islamic boarding school as a medium of harmonization. Jurnal Komunikasi: Malaysian Journal of Communication, 36(4), 323-338. https://doi.org/10.17576/JKMJC-2020-3604-20

Sulaiman, A. I., Chusmeru., Adi, T. N., Jati., P. I. P., Runtiko, A. G., \& Sutikna, N. (2020). Empowerment program design in edutourism management post pandemic covid 19. Journal of Economics and Management Sciences, 
3(3), 1-13. https://doi.org/10.30560/jems.v3n3p1

Suparto, S. P. (2012). Evaluasi program e-learning bagi petugas lapangan. Jurnal Cakrawala Pendidikan, 31(1), 102-128. https://doi.org/10.21831/cp.v0i1.1470

Suratno, S. (2018). Manajemen sistem penjaminan mutu internal sekolah dalam upaya pengembangan program akademik unggulan. Media Manajemen Pendidikan, 1(2), 217-224. https://doi.org/10.30738/mmp.v1i2.3255

Suryanto, A., Gafur, A., \& Sudarsono, F. (2013). Model evaluasi program instructorial tatap muka universitas

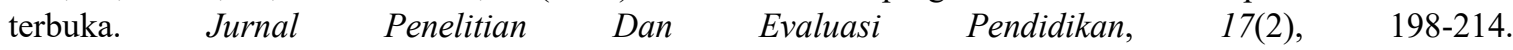
https://doi.org/10.21831/pep.v17i2.1695

Tan, E. (2013). Informal learning on YouTube: Exploring digital literacy in independent online learning. Learning, Media and Technology, 38(4), 463-477. https://doi.org/10.1080/17439884.2013.783594

Vargas, O. L. P. (2015). The quality of educational institutions: Well-trained and virtuous educational directors and teachers. Procedia - Social and Behavioral Sciences, 197, 456-459. https://doi.org/10.1016/j.sbspro.2015.07.166

Verma, G., Campbell, T., Melville, W., \& Park, B. Y. (2020). Science teacher education in the times of the covid19 pandemic. Journal of Science Teacher Education, 31(5), 483-490. https://doi.org/10.1080/1046560X.2020.1771514

Voigt, C., \& Swatman, P. (2004). Contextual e-learning evaluation: A preliminary framework. Journal of Educational Media, 29(3), 175-187.https://doi.org/10.1080/1358165042000283057

Wardrip, P. S., \& Shapiro, R. B. (2016). Digital media and data: using and designing technologies to support learning in practice. Learning, Media and Technology, 41(2), 187-192. https://doi.org/10.1080/17439884.2016.1160929

Widyaningrum, R., \& Prihastari, E. B. (2020). Student worksheet based on Surakarta's local wisdom in primary school: A preliminary research. International Journal of Science and Applied Science: Conference Series, 4(1), 2549-4635. https://doi.org/10.20961/ijsascs.v4i1.49458

Williamson, B., Eynon, R., \& Potter, J. (2020). Pandemic politics, pedagogies and practices: digital technologies and distance education during the coronavirus emergency. Learning, Media and Technology, 45(2), 107-114. https://doi.org/10.1080/17439884.2020.1761641

\section{Copyrights}

Copyright for this article is retained by the author(s), with first publication rights granted to the journal.

This is an open-access article distributed under the terms and conditions of the Creative Commons Attribution license (http://creativecommons.org/licenses/by/4.0/). 